\title{
Ficções da memória ou a memória da ficção: Dulce María Loynaz e Cecília Meireles Aimeé G. Bolaños ${ }^{1}$
}

\author{
A ficção não tem por horizonte dizer certezas \\ mas ultrapassar o limite do real. \\ Paul Ricoeur
}

De maneira instigante, Jöel Candau identifica razões práticas e culturais da memória, precisando suas operações funcionais fundamentais: ordenar o tempo, transmitir um saber e encontrar um lugar em uma linhagem, funções intimamente ligadas entre si $(2002$, p. 56) e que na ficção poética da alta modernidade, acrescentaria, carregam insólitas visões de outras realidades na superação dos códigos realista-naturalistas convencionais.

Com essa perspectiva, adentro-me na poesia de Cecília Meireles (Brasil, 1901-1964) e Dulce María Loynaz (Cuba, 1902-1997), em uma leitura atenta a suas contribuições estéticas como autoras relevantes das literaturas brasileira e cubana, hispânicas e lusófonas, artífices da palavra poética nas respectivas culturas e línguas. Também figuras que compartilham, com suas poéticas singulares, uma estética memorialista e reflexiva; simbolistas extemporâneas, avant la lettre, na verdade inclassificáveis ao fundar sua própria genealogia, além de qualquer cânone literário de época.

Interesso-me, em particular, por Últimos días de una casa (1958) e Solombra (1963), poemas-livros contemporâneos da problemática do ser na temporalidade e dos processos de constituição/destruição da identidade que acontecem, precisamente, no tempo humano da memória. Nesses poemas, Cecília Meireles e Dulce María Loynaz, ao rememorar, pensam o mundo e a poesia, além de pensar a si mesmas, fazendo ficção memorável da experiência vital e criativa.

\footnotetext{
1 Doutora em ciências filosóficas. Poeta e ensaísta, professora de literatura do Instituto de Letras e Artes e do Programa de Pós-Graduação em Letras da Universidade Federal do Rio Grande (FURG), Rio Grande, Brasil, e professora adjunta da Universidade de Ottawa, Canadá. E-mail: aimee@vetorialnet.com.br.
} 


\title{
A casa da memória visionária
}

\author{
Murmuro para mim mesma: \\ "É tudo imaginação!"
}

Mas sei que tudo é memória... Cecília Meireles

Em 1958, ano divisor de águas na história cubana², Dulce María Loynaz ${ }^{3}$ publica Últimos días de una casa $a^{4}$. Para Cintio Vitier, a poeta protagoniza uma "sibilina gesta solitária, uma aventura espiritual que pertence à história de nossos estilos, a um dos mais ocultos, penumbrosos estilos de nossa história" 5 (1993, p. 157).

Últimos días de una casa é toda uma aventura espiritual: plurívoca, de culto ao silêncio e à penumbra - quase sombra -, onde toma forma uma casa que tem voz, história e alma, quem sabe se, de certa maneira, releitura dos mistérios e moralidades medievais caracterizados pela personificação. Realmente, o poema motiva um conjunto de possibilidades interpretativas que o leitor atualizará a sua maneira.

Como sabemos, mas não seria demais recordar, desde o Simbolismo francês, que marca a mais profunda revolução poética da modernidade finissecular, o símbolo (tradicionalmente identificado com a alegoria) renova seus significados: longe de instaurar uma significação única, já codificada pela história da cultura, se abre a numerosas - alguns teóricos dizem infinitas - conotações não excludentes. O modo simbólico implica uma estratégia textual de estratos de significados, ambígua, autorreflexiva,

\footnotetext{
${ }^{2}$ O 1ํ de janeiro de 1959 triunfa a fase insurgente da Revolução Cubana, e começa um novo capítulo da conturbada história nacional.

${ }^{3}$ Sua obra poética pertence, no fundamental, à primeira metade do século XX. Últimos días de una casa marca a culminação dessa fecunda etapa criativa. Hoje é amplamente reconhecida, depois de um prolongado silêncio da historiografia literária, especialmente a cubana. A partir dos anos 1990 começam as reedições e novos livros. O Prêmio Cervantes (1993) consagra seu estatuto nas letras hispânicas. Destacam-se: Canto a la mujer estéril (1938), Versos (1920-1938), Juegos de agua (1947), Jardín (1951), Carta de amor al Rey Tut-Tank-Amen (1953), Un verano en Tenerife (1958), Poemas náufragos (1991), Bestiarium (1991), Fe de vida (1995).

${ }^{4}$ A primeira edição de Últimos días de una casa tem prefácio de Antonio Oliver. Foi feita em Madrid, na Imprenta Hermanos Soler. Significativamente, no seu colofão, aparece a data 31 de dezembro. O livro, um opúsculo de 31 páginas, fica praticamente desconhecido para o público leitor cubano. Posteriormente foi incluído em Poesias escogidas (La Habana, 1984), e tem numerosas reedições, entre elas, a de Torremozas (Madrid, 1993). Todas as citações correspondem à Antología lírica (1992, p. 203-217).

5 "Sibilina gesta silenciosa, una aventura espiritual que pertenece a la historia de nuestros estilos, a uno de los más ocultos, penumbrosos estilos de nuestra historia”.
} 
especular, em essencial correspondência (Baudelaire não é fortuito) com a natureza da mensagem estética. Como espirituosamente diz Umberto Eco: "Alguma coisa aparece, e sabemos já que é uma aparição ou não seria tão incongruente, mas não sabemos que coisa nos revela. O símbolo é uma epifania com Magos, que não sabemos de onde vêm, para onde vão, e o que vieram adorar (...) E, no entanto, fulgura" (2003, p. 44).

De inspiração narrativa e unidade temática, o poema-livro de Loynaz é constituído por 68 estrofes de versos brancos. Seu tom é solene, ainda que íntimo. Estruturado em quatro partes de extensão desigual (mais extensas as duas intermédias), consta de introdução ao tema, plenitude, agonia-paixão e morte da casa que, como foi anunciado no título, vive seus últimos dias. A casa não só é o referente maior do enunciado, mas sujeito da enunciação. Com a forma elocutória do monólogo exterior, a casa instaura-se por e em seu relato, que inclui autorretrato, retrato da família e história de vida, todas em vínculo criativo:

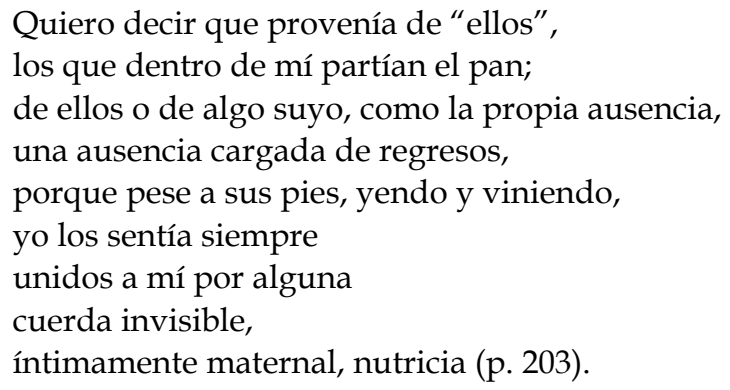

Entre a elegia e o réquiem, o sujeito discursivo casa, durante três emblemáticos dias, faz o melancólico elogio e a lamentação da perda da vida humanizada que representara; também a celebração lutuosa, com ecos cristãos, da desintegração iminente, sinalizando a onipresença da morte e os ritos do duelo. Como na épica antiga, os anúncios do fim geram uma aura trágica e, à semelhança de uma heroína de tragédia grega, a casa entrega-se a sua sina, espécie de Antígona revisitada que vai ao encontro da morte na fidelidade filial e sem claudicar de seus princípios.

A casa de Loynaz tem densidade ôntica como existência do ser e ontológica, relativa à interpretação desse ser. Antropocósmica, antropomorfa e personificada, associada a proteção, refúgio, resguardo da intimidade, constitui a matriz fecunda da memória. Na sua clássica interpretação da casa, Bachelard a caracteriza como "nosso canto do mundo (...) nosso primeiro universo. É um verdadeiro cosmos. Um cosmos em toda a acepção do termo" (1993, p. 87). 
Contudo, a casa de Loynaz não só é imagem isomorfa do cosmos mas também reflexo autoficcional especular ao ficcionalizar o sujeito-autora nessa personificação fantástica. Casa e autora estão duplicadas, portanto resultam reversíveis e se pressupõem, interpretando o jogo de espelhos típico das escrituras de si mesmo. Sendo plurissignificativa, a casa funciona a modo de metonímia do cosmos-universo e metáfora do ser no sentido existencial e histórico.

Mas a identidade da casa da ficção está ameaçada, velha, abandonada pela família e hostilizada pelo mundo circundante de casas novas, sem alma, que tomam conta da cidade. Ela se reconhece estrangeira no seu próprio reino. Imersa no silêncio e na ausência, no umbral do fim, busca amparo na memória, espaço-tempo do imaginário onde ainda é possível resistir. Dessa forma, as retrospecções, distintivas do tempo narrado, vão se enlaçando com o presente perpétuo da enunciação poética e dramática, na qual tudo está acontecendo. A casa explora diversos estratos do passado para coletar vestígios da história vivida em um tenso diálogo com o decorrer do tempo. Situada no presente da destruição e da velhice, viaja no tempo da memória. Então, os vestígios transformam-se em imagens poéticas:

Puedo hablar de mi tiempo melancólicamente, como las personas que empiezan

a envejecer, pues en verdad

soy ya una casa vieja (p. 205).

Acordes com a dinâmica multidirecional da memória, as temporalidades da ficção poética se amalgamam. Sucedem-se as lembranças de outrora, referidas ao cotidiano de uma família patrícia, na sua época áurea, alguma vez assombrada pela fatalidade (a morte de uma das filhas pequenas); mas casa, família e sociedade são vistas em uma relação harmônica de eticidade e beleza. Nessa configuração ideal do passado, a memória sacraliza as liturgias familiares:
Allá lejos
la familiar campana de la iglesia
aún me hace compañía,
y en este mediodía, sin relojes, sin tiempo,
acaban de sonar lentamente las tres...
Las tres era la hora en que la madre se sentaba a coser con las muchachas y pasaban refrescos en bandejas; la hora del rosicler de las sandías, 
escarchado de azúcar y de nieve,

y del sueño cosido a los holanes... (p. 210)

Memória de dias luminosos quando tudo anunciava a insurgência e continuidade da vida que contrasta com as sombras e o silêncio do presente da casa, cujo âmbito é fantasmal e até os móveis, de modo surreal, escapam, deixando cicatrizes, espalhadas pelo corpo-casa - memória de velada significação autoficcional, referida simbolicamente à autora como figura da ficção que se projeta na sua casa, autorreflexo e reflexo do mundo.

A narrativa da casa transcorre no incessante recordar, última estratégia de sobrevivência, em contraponto com o esquecimento da família da sua casa, que já não habita e na qual nem se reconhece. Assim, a identidade da casa existe no exercício do lembrar e ser fiel a essas recordações. As referências relativamente objetivas guardam as lembranças mais subjetivas e íntimas. Nessa agonia, onde tudo leva à morte, o poema configura uma complexa memória: grata e dolorosa, poderosa e impotente, entre a recordação e o esquecimento.

Essa memória é capaz de reviver o passado, mas esse passado traz a consciência de que não existe mais, enclausurado pelos novos tempos. A memória pode ser, também, mágica na invenção do que nunca existiu; memória reparadora em oposição à ruína, solidão e ausência do presente; memória que, embora mitifique o passado, se sabe em crise, erodida pelo avanço inevitável do esquecimento.

Nesse sentido, a imagem do mar resulta muito eloquente. Segundo Zayda Capote, a perda do mar anuncia, com a substituição do movimento perene das águas pela impessoal quietude do cimento/cemitério, a chegada da morte (1998, p. 87). Mar onipresente, absoluto no auge da casa "Cuando me hicieron, yo veía el mar" (p. 207) -, mas:

Ahora, hace ya mucho tiempo

que he perdido también el mar.

Perdí su compañía, su presencia,

su olor, que era distinto al de las flores,

y acaso percibía sólo yo.

Perdí hasta su memoria.

No recuerdo por dónde el sol se le ponía.

No acierto si era malva o era púrpura

el tinte de sus aguas vesperales,

ni si alciones de plata le volaban

sobre la cresta de sus olas... No recuerdo, no sé... (p. 207)

estudos de literatura brasileira contemporânea, n.40, jul./dez. 2012, p. 81-98 85 
Na minha leitura conjetural de Últimos días de una casa, conjugam-se interpretações promovidas pela crítica. Na opinião de Jesús J. Barquet, a simbologia da casa ${ }^{6}$ remete à modernidade: "Diante da hostilidade do avançado mundo moderno e da irresponsabilidade ou inconsciência do homem, o afã de proteção, memória e resistência de um antigo estilo de vida" (1999, p. 32, tradução nossa) ${ }^{7}$. Esse conflito tem, ademais, mais específica referência histórica, inclusive sociopolítica, vinculada à perda, na república corrupta do presente de escritura do poema, das aspirações democráticas que motivaram as guerras de independência.

Ao identificar família-casa-nação, o poema de Loynaz, assim como o pensamento de José Lezama Lima e Cintio Vitier dessa época, alude de maneira apocalíptica ao fim do estado cubano, representando a crise da identidade nacional. Na visão de Barquet, perdido o tesouro vivencial - a memória - que preserva suas paredes, "a família viverá dispersa, desprotegida, sem moradia, sem raízes nem história, na maior errância e solidão cósmica inimagináveis" (1999, p. 47, tradução nossa) $)^{8}$.

Chegando a esse ponto, perfila-se o sentido visionário do poema que pré-configura a maciça diáspora cubana a partir do triunfo revolucionário, ainda por acontecer na época da sua publicação, também antecipação de episódios autobiográficos. Em relação a sua composição, Dulce Maria Loynaz comenta anos depois: "Se você acredita em premonições, poderia pensar que foi uma delas, porque eu estava destinada a assistir à dolorosa destruição de uma casa. Mas, quando escrevi o poema, não poderia sabêlo" (1991, p. 61, tradução nossa) $)^{9}$. Não só na dimensão retrospectiva, mas prospectiva de longo alcance, cobram especial relevância os trasfegos da memória que recupera e transfigura, seleciona e imagina, esquece e recor$\mathrm{da}$, estabelecendo uma continuidade entre presente e passado, ademais,

\footnotetext{
${ }^{6}$ Ver o valioso elenco da poesia da casa: Mariano Brull, Eliseo Diego, Lina de Feria, Juana Rosa Pita, Francisco de Oráa, Rita Geada, entre outros, que Barquet (1999, p. 50) oferece, assim como sua invocação de Bachelard, especialmente no que tem a ver com as significações cósmicas do tropo da casa. Essa visão do motivo da casa na literatura cubana pode ser complementada com o estudo comparativo “Tres variaciones sobre el tema de la casa: Leopoldo Panero, Luis Rosales y Dulce María Loynaz”, de Joaquin Juan Penalva, que lê o texto de Loynaz em vínculo com poemas contemporâneos da literatura espanhola, La estancia vacía e La casa encendida, de tematização da casa. A esse sempre incompleto elenco, acrescentaria a fabulosa casa de Marcial em Viaje a la semilla (1944), de Alejo Carpentier. Na opinião de Zayda Capote, a casa de Loynaz poderia conter uma velada referência a "Historia del hombre contada por sus casas”, em La Edad de Oro (1889), de José Martí.

7 "Frente a la hostilidad del avanzante mundo moderno y la irresponsabilidad o inconciencia del hombre, el afán de protección, memoria y resistencia de un antiguo estilo de vida".

8 "La familia vivirá dispersa, desprotegida, desamorada, sin raíces ni historia, en la mayor errancia y soledad cósmicas inimaginables".

9 "Si creyera en las premoniciones, podría pensar que fue una de ellas, porque yo estaba destinada a asistir a la dolorosa destrucción de una casa. Pero cuando escribí el poema no podía saberlo”.
} 
imaginando o que virá - tempo da espera, impossível de imaginar sem a memória. Como pensa Paul Ricoeur, a memória tem orientação de mão dupla: do passado para o futuro, seguindo a flecha da mudança, e do futuro para o passado, de acordo com o movimento inverso da espera para a lembrança, por meio do presente vivo (2003, p. 130).

A poesia de Loynaz mostra a memória na sua natureza dinâmica, intimamente associada não só à mirada do passado mas aos lampejos do futuro, aquele oximoro que o Surrealismo põe em circulação quando fala das "memórias do porvir". Lembrar faz possíveis as previsões autobiográficas e históricas, não importa se com a forma da intuição, a premonição ou o vaticínio, que vem da apurada percepção do movimento temporal, seja da magna história como da íntima e pessoal, impossíveis de separar na práxis humana.

Outro viés interpretativo complementar traz Márgara Russoto, ao identificar casa e corpo da mulher, desenvolvendo o tema da degradação do corpo feminino, metaforizado na casa. Na lógica dos estudos de gênero,

a imagem da casa agonizando aponta claramente para o corpo da mulher na velhice, exercitando por sua vez com a paixão de Cristo e seus "passos" no caminho das ofensas e a destruição até a morte. A referência ao corpo devastado não se faz apenas por meio de rupturas, perfurações, úlceras e outros signos da degradação corporal que aparecem no poema, mas também por meio das ações antropomórficas que realiza a casa, que dorme, lembra, vê e experimenta dor física (2002, p. 6, tradução nossa) $)^{10}$.

Para Russoto, se a casa é um símbolo feminino, então, seria possível não só uma leitura cósmica ou sociopolítica do símbolo, mas também uma leitura articulada ao imaginário feminino, ao específico da sua posição como sujeito.

Pensando a partir dessa interpretação, diria que a casa-mulher de Loynaz, mitificação da própria condição feminina, mantém o fogo sagrado do lar, oficia no templo da família e personifica essa memória-mãe, procriadora ainda que no meio do desastre. Nesse sentido, imagino uma

\footnotetext{
10 "La imagen de la casa agonizando apunta claramente al cuerpo de la mujer en la vejez, haciendo serie a su vez con la pasión de Cristo y sus "pasos” en el camino de las ofensas y la destrucción hasta la muerte. La referencia al cuerpo devastado no se hace solamente a través de las roturas, perforaciones, úlceras y otros signos de la degradación corporal que aparecen en el poema, sino también a través de las acciones antropomórficas que realiza la casa, la cual duerme, recuerda, mira, y experimenta dolor físico".
} 
casa paradoxal, duplo de autora como figura da ficção, destruída e intacta. Assim, no clímax do poema, o sujeito autoficcional simbólico se refaz de modo deslumbrante na metáfora da pedra:

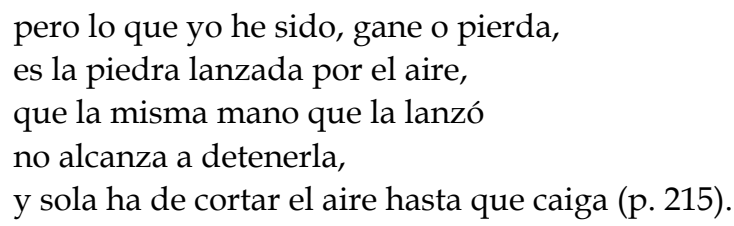

Ao indagar as experiências de solidão, de identidade ameaçada, de fim de ciclos naturais, vitais, históricos, Últimos días de una casa ancora-se na memória como alternativa humanizadora. O poema alcança seus sentidos mais transcendentais na resistência à alienação, à devastação do ser, anunciando, não sem profundas contradições e conflitos, a continuidade desses ciclos, além das destruições temporais.

Com seu pensamento simbólico e metafórico, Dulce María Loynaz olha em profundidade para si mesma, no curso da história, para iluminar constantes humanas. Sua ficção poética cria novos imaginários da dispersão, da desintegração, da morte, mas também da sobrevivência. Memorialista de um mundo que está perdendo a memória - quer dizer, sua identidade e autoconsciência -, a autora dá vida a uma indestrutível casa de símbolos:

La Casa, soy la Casa.

Más que piedra y vallado,

más que sombra y que tierra,

más que techo y que muro,

porque soy todo eso, y soy con alma. (p. 216)

\section{A memória da sombra inconsolável}

Mas era en todo caso un retorno sin pies y sin caminos, un resbalar de luz en sombra, o sombra a contraluz o sombra pura.

Dulce María Loynaz

Como ponto culminante de uma trajetória de ímpar exercício da poesia, Cecília Meireles publica Solombra ${ }^{11}$, derradeiro livro que dá a conhecer

\footnotetext{
11 Publicado em 1963, Solombra tem numerosas reedições. As citações neste artigo correspondem à edição de 2005, da Editora Nova Fronteira, com prólogo de Regina Zilberman, e que inclui Sonhos (1950-1963) e Poemas de viagens (1940-1964). Todas as citações pertencem a esta edição.

88 estudos de literatura brasileira contemporânea, n.40, jul./dez. 2012, p. 81-98
} 
um ano antes da morte. Mas isso - como a destruição da casa-famíliamundo, após 1958, de Dulce María Loynaz -, ninguém o sabe, se bem que sua autora, com a lógica imprevisível da poesia, prevê.

Solombra é um livro-poema da amorosa melancolia da morte; também das despedidas, do trânsito místico. Na interpretação de Alfredo Bosi, domina a temática da ausência (metáfora da sombra) enquanto afirmação de uma presença perdida $(1965$, p. 4). Nesse viés, o poema poderia ser lido como uma elegia de austero e sereno lirismo - abstraída e universalizada a dor existencial - e como um prelúdio e noturno de inspiração musical, possivelmente influenciado pela tradição artística das visões da alma medievais que culminam em Dante e Camões.

Em outra abordagem possível, no marco da história da literatura brasileira, João Adolfo Hansen propõe uma leitura do livro incluindo-o na grande tradição da lírica moderna, sem alardes nem estardalhaços, na dissolução das unificações ideológicas da pessoa, da memória e da comunicação, evidenciando inconformismo e não apenas regressão (2007, p. 48).

O poema constitui um diálogo transcendente da temporalidade e do ser, convocado pela memória. Diálogo de palavras de sugestiva musicalidade, mas que apela ao silêncio como suprema eloquência; concebido no claro-escuro, mas sob o domínio da sombra do perdido, do desconhecido que virá com a morte e, neste sentido, caminho ascensional. Essa sensibilidade, tanto do reino interior como filosófica universal, desdobra-se no poema intensamente estético e espiritualizado, cético e místico ${ }^{12}$, da perda e a espera:

Sobre um passo de luz outro de sombra.

Era belo não vir; ter chegado era belo.

E ainda é belo sentir a formação da ausência.

Nada foi projetado e tudo acontecido.

Movo-me em solidão, presente sendo e alheia,

com portas por abrir e a memória acordada (p. 19).

Solombra é composto por 28 rapsódias ou variações (três estrofes de três versos brancos, geralmente alexandrinos; um último verso-estrofe lapidar), as quais constituem poemas relativamente independentes que

12 Para Leila Gouvêa, Cecília Meireles é essencialmente lírica, ao mesmo tempo cética e mística, nem católica nem materialista. Não encontraria respostas na utopia marxista, nem chegaria a abraçar algum partido político, mas assumiu o avatar das lutas pela educação "no empenho da rememoração 'salvadora' pela palavra de um passado esquecido, recalcado, rememoração que recupera e dá voz aos esquecidos e vencidos da história” (2008, p. 174). 
tributam, com suas nuances temáticas e variantes compositivas, ao poema maior. Seu andamento faz pensar no adágio, tempo lento da mirada interior, dos movimentos da alma. A forma lembra a fuga musical pela dinâmica proliferativa, de variações ${ }^{13}$. O poema desenvolve-se por reiteração e um tipo de mudança significacional, que, alterando e acrescentando, mantém a identidade temática. A composição é repetitiva e progressiva, encapsulada e encadeada, sem final previsível, inclusiva de diversas visões, tons, interlocutores. Assim, um eu indefinido e sem certezas - mas, na busca existencial, polifônico pelas diferentes vozes que incorpora - compõe uma complexa trama ao dialogar consigo mesmo, o amado, o Amado místico, "alada forma" (p. 10), outras almas semelhantes; também dialogam as partes entre si e com o todo para constituir o poema de grande abrangência simbólica e deslumbrante significação plural.

A "memória indefinida e inconsolável" (p. 5), feita de sombras, metáfora dominante e recorrente, apresenta-se na entrada de Solombra, atuando como princípio criador do imaginário ${ }^{14}$, entre reminiscências e presságios. De tal maneira, todo o poema constitui-se na referência aos vestígios da memória. Se entendido vestígio ou trace como ausência de uma presença, signo sempre em deslocamento que evidencia, no seu jogo de ocultação/ exibição, as marcas deixadas pelo trânsito do $\operatorname{ser}^{15}$, então a metáfora trace, da teoria, encontra na sombra-solombra de Cecília Meireles uma das suas formas mais belamente trabalhadas.

Na fluida enunciação memorialista visionária, as lembranças e vislumbres deambulam fantasmagóricos pelo também evanescente corpo textual para tecer essa trama sinuosa, labiríntica, tão própria da identidade estética de Solombra. As imagens migram de um poema para outro e nada parece ter consistência real, salvo a todo-poderosa efêmera sombra:

Ser tua sombra, tua sombra apenas,

E estar vendo e sonhando à tua sombra

A existência do amor ressuscitada (p. 7).

\footnotetext{
${ }^{13}$ Esclarecedor resulta o verbete de Zilá Bernd sobre o tema, especialmente a parte "Entendendo a variação" (Bernd, 2010, p. 389-404).

${ }^{14}$ Ver Souza (2010, p. 247-268). Destaco as considerações de epígrafe “Um outro saber”, em que a autora, identificando memória e imaginação, afirma: "A beleza da memória está justamente na sua capacidade de ficcionalmente tornar presentes as imagens passadas” (p. 257).

${ }^{15}$ Ver Bernd (2011, p. 9-15). Nesse artigo pode ser encontrado um valioso percurso teórico sobre o conceito de trace, também vestígio, resto, resíduo, ruína. De modo significativo, ao falar de traces, a autora alude às presenças fantasmais, citando Derrida, e refere-se ao texto poético semelhante a uma casa assombrada (p. 11).
} 
No espírito das declarações estéticas do Simbolismo, o artista acredita no que não toca nem vê, mas sente, como o sujeito poético de Cecília Meireles diz: "Só vejo o que não vejo e que não sei se existe" (p. 6). Assim, o modo simbólico domina na tentativa de dizer o indizível. Nessa dimensão, o espaço desprende-se dos lugares, o tempo separa-se dos ponteiros e "tudo se vai, tudo se perde" (p. 14).

Na enunciação dramática do poema, a "memória acordada" tenta reviver e conservar o perdido, que pode ter o rosto dos seres amados, em fuga, inalcançáveis, também a forma das utopias de vida. Mas essa mulher da ficção, que no poema se faz/desfaz, está se despedindo "solitária de mim, repentina exilada" (p. 14). A língua do mundo torna-se estranha, estrangeira, e sua alma "tão desconhecida / vai ficando sem mim, livre em delícia" (p. 8), em uma jubilosa tristeza. E, embora se saiba ilha "onde eu mesma nada sei fazer por mim" (p. 8), quer a clarividência do instante que habita para interrogar o mundo, procurando últimos sentidos, e buscar em si mesma "os enigmas ardendo" (p. 14). Aparecem interrogações ontológicas capitais, que pairam em todo o poema, sobre o ser ontológico - a poeta, o sujeito discursivo, os leitores, o gênero humano - e o ser da poesia. O sujeito poético pergunta-se: "Qual será meu destino verdadeiro" (p. 20); “De onde vem a morte?" (p. 20); “E que vida oferece a voz que canta? (p. 21), "quem fomos? quem seríamos? quem somos?" (p. 21).

Nessa dimensão questionadora, apenas se poderia afirmar uma "fervorosa vontade de resgate através de perguntas e não através da aceitação servil da resposta" (Eco, 2003, p. 146), postura estética distintiva da modernidade que, segundo Eco, reinventa o conceito de poesia, não apenas enciclopédia ou ilustração, relato ou moralidade: o leitor moderno agora espera as fulgurações simbólicas.

Peregrina, a memória viaja em si, salvando essências e dando vida a um "pálido mundo, só de memória" (p. 20). É um demiurgo, portanto, mágica, imaginária. Nesse universo inconsútil, feito de e pela memória, tudo se espiritualiza. Quanto existe, cobra alma em imagens nas quais surrealismo e simbolismo se dão a mão, além de poéticas programáticas. Essa memória mágica, irmã do sonho e da morte, faz possíveis metamorfoses fantásticas, como acontece com a noite, "jardim de puro tempo / com ramos de silêncio unindo os mundos" (p. 20), lugar mítico de encontros, de sonhos de renascimento, de ressurreição do amor na forma místico-erótica. Atrelada à memória, a imaginação visionária vê:

Caminho pelo acaso dos meus muros,

Buscando a explicação dos meus segredos.

E apenas vejo mãos de brando aceno, 
olhos com jaspes frágeis de distância,

lábios em que a palavra se interrompe:

medusas da alta noite e espumas breves (p. 9).

Essa memória da ficção, essa ficção da memória, tem inspiração rizomática ${ }^{16}$. Distingue-se pelos diferentes pontos de eclosão, sem chegada nem partida, multiforme nas suas ramificações espaciais e temporais, a modo de "planta crescente / com mil imagens pela seiva resvalantes, / na noite vegetal que é a mesma noite humana" (p. 19). Em Solombra tudo está em movimento, efêmero, volátil. Sua estruturação acolhe e espalha significados instáveis, inacabados, de variações que transbordam sentidos.

Nessa sensibilidade movediça, de contactos imprevisíveis e associações insólitas, a natureza - ecoando os pilares do templo de Baudelaire em "Correspondências" - deixa sair suas vozes misteriosas, confundidas as sensações em um tipo de sinestesia de intensas ressonâncias espirituais. O mundo poético de Cecília Meireles em Solombra, semelhante à "medusa de alta noite" que o sujeito poético já viu, pertence à linhagem das sombras, ecos, reverberações, secretas correspondências. Sua visão é de reflexos prismados.

As palavras gastas de Amor e Morte olham-se no espelho da Beleza sonhada, maior que a vivente (p. 16). O poema volta-se sobre si como obra poética, feita de palavras, espaço do imaginário onde sonho e memória dialogam para criar estranhas cenas evanescentes e brilhantes. Cecília Meireles, que tantas poetas foi, tematiza o canto, seu canto. A "memória acordada" ainda tem portas por abrir:

Uma vida cantada me rodeia.

Mas pergunto-me até onde me alcança

o canto que me envolve e protege (p. 21).

Contudo, ante o reclamo do canto, "as palavras são conchas secas, bradando / a vida, a vida, a vida! E sendo apenas cinza. / E sendo apenas longe" (p. 5). Desde as imagens iniciais anuncia-se sua poética e prática autorreflexiva: "Entre as mãos tristes, vê-se a harpa imóvel" (p. 5). O texto descobre e desenvolve sua vocação metaficcional, que, de maneira explícita ou, às vezes, por alusão, funciona como baixo contínuo do discurso de Solombra. Nessa estética metaficcional resulta recorrente a reflexão sobre os modos de perceber, recordar e, por conseguinte, compor e, muito especialmente, sobre a palavra poética no paradoxo de sua precariedade e poder gerador. No viés metapoético, o ser do poema, duplo ou sombra do

\footnotetext{
${ }^{16}$ Evidentemente, utilizo o conceito de Deleuze e Guattari (1995).
} 
eu poético, padece sua frágil estrutura, perto da ruína (p. 13). Com total consciência artística, o sujeito discursivo escolhe as palavras do sonho, da infância e da morte, para "dizer com claridade o que existe no segredo" (p. 7).

Ao interpretar o tema da metapoesia, a autora da ficção assume-se poeta $^{17}$, mostra sua condição de mulher-artista e pensa sua poética no exercício do canto. Aprofunda-se na dimensão autoficcional especular. Nessa tessitura, reiteradamente olha para si no espelho do poema: “Vejome longe e perto, em meus nítidos moldes/ em tantas viagens, tantos rumos prisioneira" (p. 19). E, ao falar de si mesma como outra, faz um autorretrato se enxergando no olho da poesia que está criando e da qual é criatura. Dessa maneira, aparece dúbia, ambígua, paradoxal: “Não se sabe se é morta e parada em beleza / ou viva e acostumada às condições da morte" (p. 20).

Ao recorrer, lúcida e delirante, o caminho do autoconhecimento e autoengendramento na poiesis, a memória desvela a alma e alcança sentido liberador: "Eu sou essa pessoa a quem o vento ensina: / Agora és livre, se ainda recordas." (p. 16). Pessoa de sombras translúcidas que, embora entrando no olvido dos outros, cumprirá os deveres da memória. Não esquecerá o amor nem as figuras amadas, que continuam a existir na memória do poema.

Retomando a leitura de Hansen, Solombra "configura a experiência de algo ausente, algo que faz falta no presente, que simultaneamente é perdido, passado, e ideal, futuro" (2007, p. 35). O poema, como representação da alma, longe de se fechar, expande-se na ascensão espiritual por meio do logo, neste caso, da palavra poética. Unindo as dimensões esotéricas e estéticas, Cecília Meireles deixa entrever uma via de reunificação com a realidade suprema e última, com o puro ser. A morte não é fim, só passagem.

Finalmente, os vestígios da dor existencial no mundo da vida serão apagados em um outro mundo, de ar, sem tempos nem ecos. Nesse mundo da morte, esvaído na distância, o ser transforma-se em abraços que perderam sua forma: "Tão de adeuses / que já nem temos mais despedidas" (p. 23). Cessam as frágeis perguntas existenciais; os diálogos impossíveis ficam suspensos. Culmina o rito do esquecimento perfeito, até do nome próprio que jaz entre as antigas mortes, pois "só nessas mortes pode estar meu nome escrito" (p. 22).

\footnotetext{
17 Uma leitura de gênero aporta Maria Lúcia Dal Farra. Curiosamente, assim como no caso de Dulce María Loynaz, é discutida a escolha lexical de poeta ou poetisa para as autoras mulheres. Seu artigo também oferece um válido percurso pela “fortuna crítica” de Meireles. Ver Dal Farra (2006).
} 
A figura fantasmal contempla o ser profundo, ao vislumbrar outras formas de saber, não mais racionais excludentes, imagináveis no pensamento místico que anula as diferenças e não reconhece fronteiras no caminho ascensional. Com uma iluminada compreensão da memória, além da oposição de recordação e olvido ${ }^{18}$, a poeta diz: "Assisto - amarga: recordando-me e esquecendo-me" (p. 22). Conhecedora de outra dor, de outra esperança, quem sabe se de renascimento ou ressurreição na poesia, acolhe-se no êxtase do silêncio.

\section{Escribas da memória devastada e incólume}

Sem tentar igualar poemas que são inigualáveis, nem relacionar poetas que nunca se conheceram nem leram uma à outra, identifico uma poética da memória devastada e incólume em Dulce María Loynaz e Cecília Meireles, que arroja luz sobre a sociabilidade estética da alta modernidade latino-americana. Estrangeiras, ilhadas, na solidão e no silêncio, cultuam os rituais da memória. Nelas, fazer memória resulta tanto uma necessidade como dever primordial. Em um mundo que está perdendo a espiritualidade, reconfiguram os vestígios da memória injuriada, mutilada, ferida de morte.

Nessa ordem cosmovisiva, ressalta a poetizacão da experiência de perda ao mergulhar nos abismos da destruição. Em Últimos días de una casa e Solombra, os saberes são organizados pela memória imaginária que dá vida às traces do memorável, protagonizados os poemas por uma figura de múltiplas formas: mulher-casa ou mulher-sombra, ser de tempo e intemporal, pessoa, poeta, eu, flagrada no transcendente ato de recordar.

Tanto Cecília Meireles como Dulce María Loynaz são líricas e filósofas da existência, que pensam o ser e o tempo no centro das contradições e de modo paradoxal, ultrapassando os limites metafísicos das certezas, sem os lugares-comuns do discurso historiográfico ou filosófico intelectualizante, mais preocupado com fatos e categorias em interpretações fechadas. Na sua poesia, os motivos literários da morte, amor, família, passagem do tempo, identidade ameaçada, transitoriedade, permanência são reinterpretados de maneira heterodoxa - a personificação de uma casa, a corporização das sombras -, os significados abertos, irradiantes, reversíveis no movimento metaficcional simbólico.

\footnotetext{
${ }^{18}$ Nas palavras de Todorov, “a memória não se opõe absolutamente ao esquecimento. Os dois termos contrastantes são o apagamento (o esquecimento) e a conservação; a memória é, sempre e necessariamente, uma interação entre os dois” (1995, p. 14)
}

94 estudos de literatura brasileira contemporânea, n.40, jul./dez. 2012, p. 81-98 
Ambas compartilham o traço comum do exílio espiritual, patente na luta pela preservação da integridade ameaçada e a resistência às forças exteriores da alienação. Esse exílio é voluntário, deliberado, ciente das suas estratégias e riscos. Implica, nos poemas lidos, uma volta à matriz da casa e da sombra, onde as figuras da ficção buscam, diante da morte, o elo perdido e se abrem ao desconhecido porvir. Os eus reminiscentes dos poemas, voltados para o passado, também são visionários: olham à sua frente longe porque, e nas palavras de Lévinas, todo movimento humanizador é excêntrico $(1975$, p. 28). Daí a dimensão projetiva da memória nos poemas, seus significados emergentes, ideais, muito expressivos desse exílio espiritual das poetas; dimensão reparadora e de voo libertador.

Em Dulce María Loynaz e Cecília Meireles a memória é anima mundi, mundo da alma e alma do mundo. E, sendo assim, seu simbolismo transhistórico dá testemunho da complexidade, não poucas vezes inexpressável, do universo subjetivo, da alma. Essa sensibilidade está perto de Fernando Pessoa, precursor e mestre da alta modernidade, para quem a imaginação poética é "como de alguém que conhecesse a alma das coisas, e lutasse para recordar esse conhecimento, lembrando-se de que não era assim que as conhecia, não sob aquelas formas e aquelas condições, mas de nada mais se recordando" (1986, p. 36-37).

Nessa compreensão espiritualista, as poetas conformam suas visões estremecidas e desestabilizadoras, de "espanto, admiração, como de um ser tombado dos céus, a tomar plena consciência de sua queda, atônito diante das coisas" (1986, p, 37), e invoco de novo a Pessoa. Criam de modo original, ao recuperar as origens e essências desde o próprio encantamento e espanto, no pertencimento a uma genealogia artística que vai da literatura medieval alegórica à eclosão da modernidade - Baudelaire, Verlaine, Rimbaud, Pessoa, figuras icônicas -, recriando símbolos de antiga linhagem na história da poesia com suas metáforas de invenção, portanto, vivas.

Lidos hoje, Últimos días de una casa e Solombra, no hermetismo e transparência de seus símbolos, continuam fulgurando sentidos, não poucas vezes, desconcertantes, para incitar-nos a outras leituras de imprevisíveis ressonâncias, na consciência crescente de que "o modo simbólico estará lá onde finalmente tivermos perdido a vontade de decifrar a qualquer custo" (Eco, 2033, p. 143). Os poemas de Dulce María Loynaz e Cecília Meireles dão fé de seu extraordinário oficio de escribas da memória, onde tudo fica escrito e inscrito no tempo humano e - quero imaginar - no tempo sem fim da poesia. 


\section{Referências}

BACHELARD, Gastón (1993). A poética do espaço. São Paulo: Martins Fontes. BARQUET, Jesús J. (1999). “Testimonio de una destrucción: últimos días de una casa de Dulce María Loynaz". In: Escrituras poéticas de una nación: Dulce María Loynaz, Juana Rosa Pita y Carlota Caulfield. La Habana: Unión.

BERND, Zilá (2010). “Variações”. In: Dicionário das mobilidades culturais: percursos americanos. Porto Alegre: Literalis.

(2011). "Vestígios memoriais: fecundando as literaturas das Américas". Conexão Letras, v. 6, n. 6, p. 9-16.

BOSI, Alfredo (1965). "Cecília Meireles: a música ausente". O Estado de S. Paulo, São Paulo, suplemento literário, p. 9.

CANDAU, Jöel (2002). Antropología de la memoria. Buenos Aires: Nueva Visión. CAPOTE, Zayda (1998). “El arte de la paradoja: la poesía de Dulce María Loynaz". In: CAMPUZANO, Luisa (coord.). Mujeres latinoamericanas del siglo XX: historia y cultura. La Habana: Casa de las Américas.

DAL FARRA, Maria Lúcia (2006). "Cecília Meireles: imagens femininas". Cadernos Pagu, n. 27, p. 333-371.

DELEUZE, Gilles; GUATTARI, Félix (1995). Mil platôs: capitalismo e esquizofrenia. v. 1. Rio de Janeiro: Editora 34.

ECO, Umberto (2003). "Sobre o símbolo". In: Sobre a literatura. Rio de Janeiro; São Paulo: Record.

HANSEN, João Adolfo (2007). "Solombra ou a sombra que cai sobre o eu". In: GOUVÊA, Leila V. B. (Org.). Ensaios sobre Cecília Meireles. São Paulo: Humanitas, Fapesp.

GOUVÊA, Leila V. B. (2008). Pensamento e "lirismo puro" na poesia de Cecília Meireles. São Paulo: Edusp.

LÉVINAS, Emmanuel (1975). Sens et existence. Paris: Seuil.

LOYNAZ, Dulce María (1958). Últimos días de una casa. Prefácio de Antonio Oliver. Madrid: Hermanos Soler.

(1993). Antología lírica. Introducción de María Asunción Mateo. Madrid: Espasa-Calpe.

MEIRELES, Cecília (1963). Solombra. Ilustrações de Pomar. Rio de Janeiro: Livros de Portugal.

Fronteira.

(2005). Solombra. Prólogo de Regina Zilberman. Rio de Janeiro: Nova

PENALVA, Joaquín Juan (2002). “Tres variaciones sobre el tema de la casa: Leopoldo Panero, Luis Rosales y Dulce María Loynaz". América sin Nombre, n. 3. p. 48-55.

PESSOA, Fernando (1986). Obras em prosa. Rio de Janeiro: Nova Aguilar.

RICOEUR, Paul (1973). Teoria da interpretação. Lisboa: Edições 70. Janeiro: Imago. (1983). O conflito das interpretações: ensaios de hermenêutica. Rio de 
(1999). La lectura del tiempo pasado: memoria y olvido. Madrid: Universidad Autónoma de Madrid.

RUSSOTTO, Márgara (2002). “Casa, cuerpo, pasión: una lectura de Últimos dias de una casa". CiberLetras, n. 7. Disponível em: <http:/ / www.lehman.cuny. edu/ciberletras/v07.html>. Acesso em: 15 out 2011.

SIMÓN, Pedro (coord.) (1991). Valoración múltiple: Dulce María Loynaz. La Habana: Casa de las Américas.

SOUZA, Raquel (2010). "Memória e imaginário". In: BERND, Zilá (Org.). Dicionário das mobilidades culturais: percursos americanos. Porto Alegre: Literalis.

TODOROV, Tzvetan (1995). Les abus de la mémoire. Paris: Arléa. VITIER, Cintio (1993). Prosas leves. La Habana: Letras Cubanas.

Recebido em novembro de 2011.

Aprovado em março de 2012.

\section{resumolabstract}

Ficções da memória ou a memória da ficção: Cecília Meireles e Dulce María Loynaz

Aimeé G. Bolaños

Dulce María Loynaz e Cecília Meireles são lidas como poetas que compartilham, com suas poéticas singulares, uma estética memorialista e reflexiva, simbolistas extemporâneas, inclassificáveis. Sobre temporalidade, saberes e genealogia, funções principais da memória, reflete este artigo que se aprofunda em Últimos dias de una casa (1958) e Solombra (1963), poemas-livros da problemática do ser na temporalidade e dos processos de constituição/destruição da identidade que acontecem, precisamente, no tempo humano da memória. Estudam-se esses poemas de ficção do memorável nas suas diferenciadas formas de compor e significar ao coletar e preservar vestígios da memória injuriada, mutilada, ferida de morte, configurando uma volta ao passado imaginado, mas também uma abertura às "memórias do porvir" em uma poética paradoxal da memória incólume e devastada.

Palavras-chave: poéticas da memória, vestígios, simbolismo, poesia brasileira e cubana, Cecília Meireles, Dulce Maria Loynaz.

Fictions of memory or the memory of fiction: Cecília Meireles and Dulce Maria Loynaz

Aimeé G. Bolaños

Dulce María Loynaz e Cecília Meireles are read as poets that share, with their singular poetics, a memorialistic and reflexive aesthetics, in the condition of symbolist poets untimely. This article thinks about temporality, knowledge and genealogy, main memory's functions, and examines Últimos días de una casa (1958) and 
Solombra (1963), poems-books on the problematic of the being in the temporality and the process of doing/undoing identity that occur, precisely, in the human time of memory. These poems of memorable fiction are studied in their different forms of composition and meanings when they pick up and preserve traces of offended, mutilated and deadly hurt memory in order to look at the pass and, also, to the future in a paradoxical poetics of a wasted and uninhabited memory.

Keywords: poetics of the memory, traces, symbolism, Brazilian and Cuban poetry, Cecília Meireles, Dulce Maria Loynaz. 